\title{
Application of Safety Education on Junior High School Teaching Materials
}

\author{
$1^{\text {st }}$ Evi Widowati \\ Dept. of Public Health \\ Universitas Negeri Semarang \\ Semarang, Indonesia \\ eviwidowati@mail.unnes.ac.id
}

\author{
$2^{\text {nd }}$ Herry Koesyanto \\ Dept. of Public Health \\ Universitas Negeri Semarang \\ Semarang, Indonesia \\ dhim45ku@yahoo.co.id
}

\author{
$3^{\text {rd }}$ Sugiharto \\ Dept. of Public Health \\ Universitas Negeri Semarang \\ Semarang, Indonesia \\ giek.kribo@mail.unnes.ac.id
}

\begin{abstract}
Children in junior high school are stand in transitional period between elementary and senior high school. These junior high school students are still on the period of growth and development. Therefore, they are included as vulnerable group. They always want to move and have excessive energy, so that they have a very high risk of experiencing accident, either at school or at home. In contrast, education of safety for children in school is very minimal, either in formal education (within teaching materials, educational process, and learning facilities) or in informal education through extracurricular activities. The study design used was quantitative-descriptive with observational approach. Primary data collection was performed through Focus Group Discussion with teachers and school managers, while secondary data was obtained through documental study of teaching materials from $7^{\text {th }}$ to $9^{\text {th }}$ grade. The result showed that teaching materials, which contained education of safety, were $30.21 \%$ in $7^{\text {th }}$ grade, $6.43 \%$ in $8^{\text {th }}$ grade, and $28.13 \%$ in $9^{\text {th }}$ grade. The advice given was to increase teacher competency in applied safety science, so the teachers can develop their teaching materials into the real example during teaching process. Furthermore, the teachers can integrate the education of safety on thematic subjects or extracurricular.
\end{abstract}

Keywords—teaching materials, safety, junior high school

\section{INTRODUCTION}

Children of junior high school are still on the growth and development period, so they are included in vulnerable group. Their age is within the transitional age between elementary school and senior high school. In general, they are always want to move because of their excessive energy. Furthermore, they also have high curiosity related to new things around them. As the result, there are many accidents, either minor or major accidents, occur during their activities, such as during playing, exercising, crossing the road, and going home. These accidents are sometimes make a panic situation in school. Therefore, comprehensive prevention of accident in children, either through enhancement of knowledge of student, the role of teachers, school management, parents, school committee, and the others are needed [1].
Current facts show that generally all human activities are having risk of endanger the safety either themselves or others. Accidents can take place because of several factors. One of them is knowledge level of safety education in children. Limited knowledge of safety education are potentially caused either mild or serious accidents, even death. On several cases, accidents happened in children were causing serious injury and death.

School accidents data from School Health Unit (UKS) of PL. Benadus 02 in Semarang showed that the students ever experienced accidents during walking, running, or exercising. There are 9 students suffered from injuries and 5 student, who were referred to the hospital due to bone fracture and sprain after running and falling [2]. Moreover, study from Olowokere (2016) showed that in public school there are limited health care provider to fulfill the need of health service for children [3].

On the other hand, substantive formal educations on school subjects are densely given in the current curriculum. Education of safety for children in school is very minimal, either in formal education (within teaching materials, explanation from the teachers during learning activities, and owned learning facilities) or in informal education (within extracurricular activities).

A study by Widowati (2017) showed that safety education is still needed in elementary school. In the $1^{\text {st }}$ grade, $60 \%$ of the educational subjects already have safety education content. In the $2^{\text {nd }}$ grade, there were only $14.3 \%$ educational subjects that contain safety education, which was included on civic education subject. Meanwhile, in $3^{\text {rd }}, 4^{\text {th }}, 5^{\text {th }}$, and $6^{\text {th }}$ grade, there were $14.3 \%, 90 \%, 100 \%, 87.5 \%$, and $50 \%$ educational subjects with safety education content, respectively [4].

In order to obtain illustration of safety education in basic education level, we must start from elementary school, junior high school, to senior high school. In this study, we aimed to understand the illustration of materials and facilities of learning, which were available in junior high school. 


\section{MATERIALS AND MethodS}

Our study used quantitative descriptive design with observational approach. This study used Focus Group Discussion (FGD) to collect primary data and documental study to collect secondary data. The FGD involved teachers and school's management. We performed the FGD to understand, theoretically and practically, the implementation of safety education for student in junior high school based on their point of view. Meanwhile, documental study was performed by reviewing the subjects of teaching materials for the $7^{\text {th }}$ to $9^{\text {th }}$ grade of junior high school. The secondary data was obtained to understand whether the safety education included explicitly or implicitly on the each subjects.

This study performed on only one public junior high school in Indonesia because of junior high school in Indonesia have almost similar standard, which is set by National Education Authorities in Indonesia. The data were analyzed descriptively.

\section{RESULTS AND DISCUSSION}

Generally, of 11 educational subjects $(100 \%)$ in the $7^{\text {th }}$ grade, allalready contained safety education, although it was not included in every chapter.

Three of eleven $(27.3 \%)$ educational subjects in the $8^{\text {th }}$ grade (social sciences, Javanese language, and Islamic education) did not contain safety education contents. Meanwhile, in the $9^{\text {th }}$ grade, there were only 2 of 15 (13.3\%) educational subjects (social sciences and mathematics), which did not contain safety education contents. However, in every subjects on $8^{\text {th }}$ and $9^{\text {th }}$ grade, which contained safety education contents, it was not included in every chapter of the subjects.

1. Analysis of safety education on teaching materials in the $7^{\text {th }}$ grade

The $7^{\text {th }}$ grade had 11 subjects as follows: English language, Islamic education, civic education, Indonesian language, mathematic, art and culture, Javanese language, social sciences, sport and health education, natural sciences, and workshop. They had 105 chapter and 422 theme.

From the illustration above can be concluded that in the $7^{\text {th }}$ grade, civic education and social sciences had the highest percentage of safety education contents $(56 \%)$. On the other hand, art and culture had the lowest percentage of safety education contents $(5 \%)$.

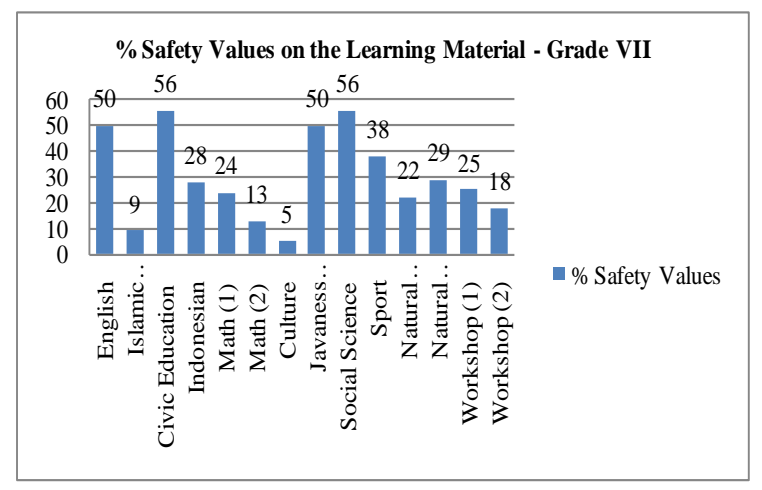

Fig. 1. Illustration of Safety Education on Teaching Materials in the $7^{\text {th }}$ grade

2. Analysis of safety education on teaching materials in the $8^{\text {th }}$ grade

The $8^{\text {th }}$ grade had 11 subjects as follows: English language, Islamic education, Pancasila and civic education, Indonesian language, mathematic, art and culture, Javanese language, social science, sport and health education, natural science, and workshop. In total there were 112 chapters and 424 themes.

Subject of workshop had the highest percentage of safety education contents, which was $24 \%$ on the $2^{\text {nd }}$ semester and $22 \%$ on the $1^{\text {st }}$ semester. On the other hand, these following subjects did not contained safety education: social science, natural science on the $2^{\text {nd }}$ semester, Javanese language, Islamic education, and mathematic on the $2^{\text {nd }}$ semester.

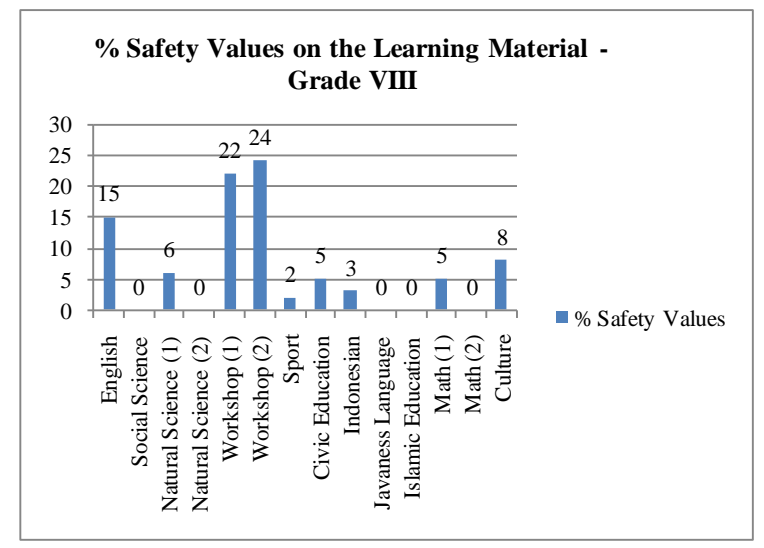

Fig. 2. Illustration of Safety Education on Teaching Materials in the $8^{\text {th }}$ grade

3. Analysis of safety education on teaching materials in the $9^{\text {th }}$ grade

The $9^{\text {th }}$ grade had 11 subjects as follows: English language, Islamic education, civic education, Indonesian language, mathematics, art, Javanese language, social science, natural science, biology, and physic. In total there were 124 chapters and 284 themes. These subjects were supported by 15 teaching materials to prepare the student to take on national exam (UN). 
Islamic education subject had the highest percentage of safety education contents $(100 \%)$. On the other hand, social science and national exam enrichment material for mathematics subject had the lowest percentage (0\%) (Fig. 3).

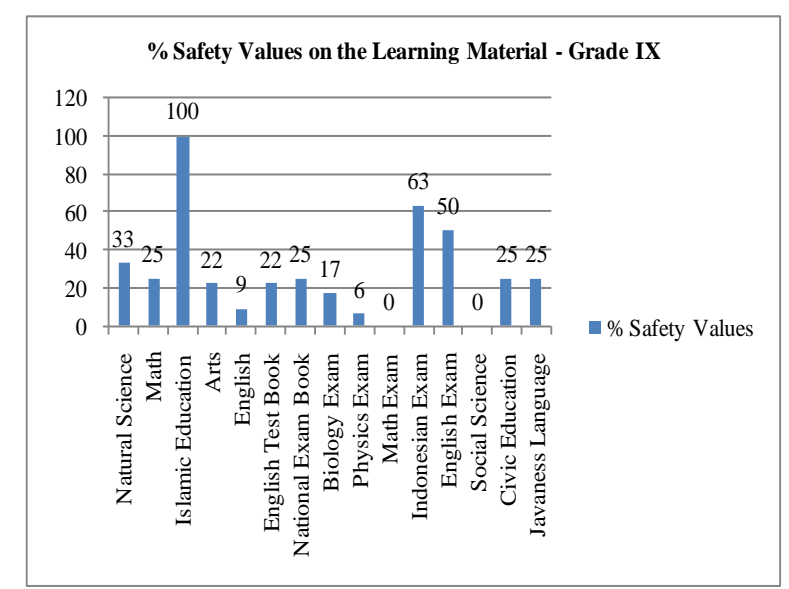

Fig. 3. Illustration of Safety Education on Teaching Materials in the $9^{\text {th }}$ grade

4. Illustration of Total Safety Education in All Grades

In all grades, percentage of subjects without safety education were higher than subjects with safety education (Fig. 4). The $8^{\text {th }}$ grade had the lowest percentage of subjects with safety education.

In details, among 422 themes in all subjects on the $7^{\text {th }}$ grade, there were $30.21 \%$ themes with safety education. Among 424 themes in all subjects on the $8^{\text {th }}$ grade, there were only $6.43 \%$ themes which have content of safety education. Furthermore, among 284 themes in all subjects on the $9^{\text {th }}$ grade, there were $28.13 \%$ themes have safety education contents.

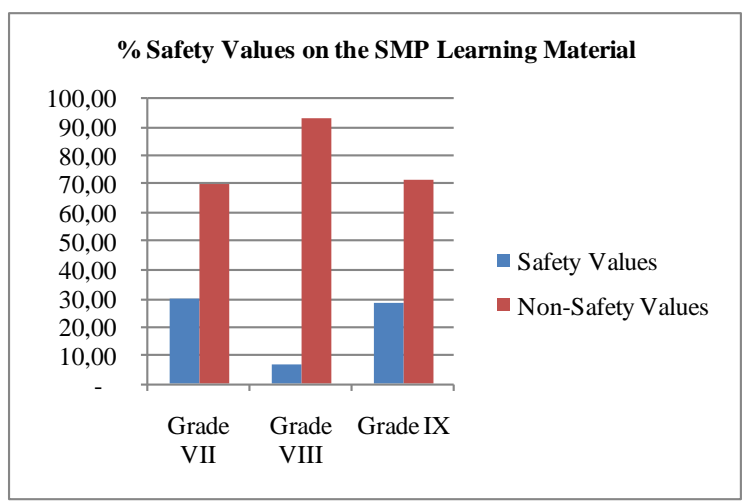

Fig. 4. General illustration of safety education on junior high school's teaching materials

\section{Method of Delivering Safety Education Contents in Every} Grades

Themes of subjects in all grades had the safety education content, either implicitly delivered or explicitly delivered (Fig.
5). Though, it seemed on figure shown that themes that had no contain of application of safety education was more than themes that had contain, either implicitly or explicitly delivered.

In details, among 422 themes in all subjects on the $7^{\text {th }}$ grade, there were $30.21 \%$ themes with safety education and $23 \%$ of them were explicitly delivered on the teaching materials.

Among 424 themes in all subjects on the $8^{\text {th }}$ grade, there were only $6.43 \%$ themes with safety education and $5 \%$ of them were explicitly delivered on the teaching materials. Moreover, among 284 themes in all subjects on the $9^{\text {th }}$ grade, there were $28.13 \%$ themes with safety education and $13 \%$ of them were explicitly delivered on the teaching materials.

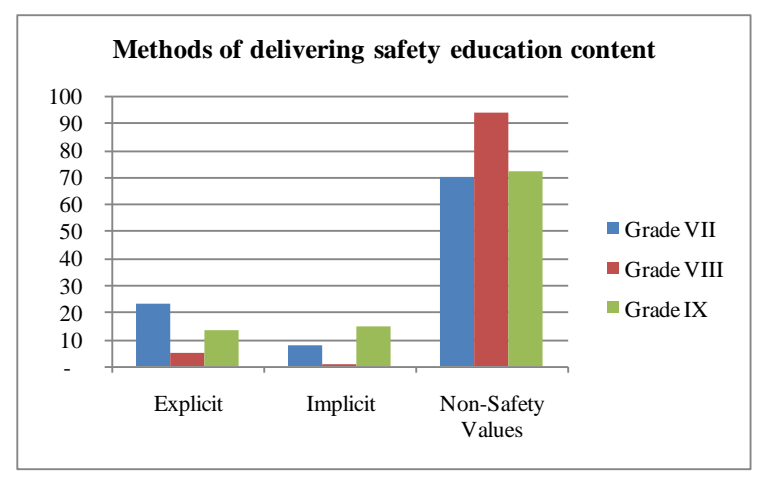

Fig. 5. General illustration of method of delivering safety education content on teaching materials

Meanwhile, FGD result showed that several subjects had safety education content, such as English language in transportation theme on the road and sport. In addition to formal education, there were safety education on extracurricular activities, such as scout and swimming. However, the teachers agreed that there were many subjects without safety education on their school. The teachers also said that they had competency to improvise and integrate the available themes of subjects into the example of applied safety education. Nevertheless, they only can give example on safety education aspect related to daily living. Therefore, majority of the teachers said that they need courses related to safety education to enhance their knowledge. Meanwhile, the teachers said that Health Care Unit room and drugs supply were below the standard. The stairs and the availability of fire extinguisher were also below the standard, especially on the laboratory.

We concluded from the illustration previously that safety education on junior high school was minimal, either on "national (Diknas)" subjects, local subjects, thematic subjects, or practical subjects on the laboratory. These findings were similar with a study by Sukarmin, which revealed that implementation of safety education by sport teacher in elementary school was only included in the category of "fair". In quality, sport teacher in elementary school already had awareness and ability to provide sport education safely, 
although it was not optimal. Effort made by sport teacher in elementary school was not sufficient to reach all aspect, which were involved in sport educational process, especially nontechnical aspect [5].

Meanwhile in Indonesia, safety education is very important, because Indonesia has high potential of natural disaster. According to a research by Sakurai, in 2004, 56\% of elementary school in Banda Aceh were located in the area, which was prone to tsunami. Education authorities in Banda Aceh stated that, in 2014, there were 21.301 students that had potential to get the impact of tsunami. Through recovery support after disaster, the reduction of the risk of natural disaster had been performed by the external parties in Banda Aceh to improve safety in the school. The effort of reducing the risk including the reconstruction of the building with two floors, the making of evacuation route and safety sign, the training of evacuation, the preparation and development of relevant educational subjects. However, the continuity of these activities were not adequate, because of the external parties was not involving local citizens and was causing "dependency". Moreover, the head of the school did not realize that they had responsibility to ensure the continuity of these activities [6].

On the other hand, activities of children had several potential risk of danger that may threaten their safety. According to a research by $\mathrm{Li}$, children still had low awareness toward the use of sanitation facility and water on hygiene practice, including washing hands before eating. There were many students that walk on the cross road, which is not safety for children, either because of no available traffic signs or uneven grounds. These condition might put the children in danger, either while playing or being outside the classroom [7].

Similar result also found by Yusvita. There were 40-50\% of students, who were capable of identified the potential danger and the risk of several potential of danger around them, such as stairs can cause falling, slippery floor can cause slipping and injury, motor vehicle can cause traffic accident, and non-hygienic food or environment can cause disease. In addition, not all students capable of re-explaining about safety sign in school, including traffic sign [8].

There were many students, who were not capable of using practical tools according to the procedure, even after proper explanation by the teacher. Furthermore, there were students, who did not keep their practical tools in the right place. As the result, these tools had potential of broken or can cause accident.

Therefore, massive, holistic, and comprehensive safety education is needed to ensure the safety of the children, considering them as the next generation of the country. Education is the process of learning that can enhance the ability of the children, either cognitive, affective, or psychomotor. These model of education also can be applied in the field of safety. In order to help student achieve success in learning, the curriculum about safety education in school is needed.

In order to change the perception and paradigm of the citizens about safety, the safety education and its continued socialization must be performed. These program must be performed since the early age to grow the sense of discipline. Therefore, the value of safety can be adopted to applied daily value, such as discipline in traffic, safely crossing road, and the others [9].

The example of safety education is the one that applied in Malaysia. They arrange the system of safety in school laboratory using 5P approach as follows: (1) working procedure, (2) safety tools, (3) experimental control, (4) chemical waste disposal, and (5) emergency procedure. This approach is a comprehensive way for the students, teachers, or laboratory assistant to implement safety values while working on the laboratory. It is considered sufficient in preventing nondesirable event in school, which was highly reported and inviting the concern of all parties [10].

\section{CLOSING}

The conclusion of current study is: Generally, 11 educational subjects $(100 \%)$ in the $7^{\text {th }}$ grade already contained safety education, although it was not included in every chapter. These subjects were as follows: English language, Islamic education, civic education, Indonesian language, mathematic, art and culture, Javanese language, social sciences, sport and health education, natural sciences, and workshop. They had 105 chapter and 422 theme. There were $30.21 \%$ themes with safety education and $23 \%$ of them were delivered explicitly on the teaching materials.

Three of eleven $(27.3 \%)$ educational subjects in the $8^{\text {th }}$ grade did not contain safety education contents. These subjects were social science, Javanese language, and Islamic education. The $8^{\text {th }}$ grade had 11 subjects as follows: English language, Islamic education, Pancasila and civic education, Indonesian language, mathematic, art and culture, Javanese language, social science, sport and health education, natural science, and workshop. They had 112 chapters and 424 themes. There was only $6.43 \%$ of the subjects, which contained safety education, and $5 \%$ of them were delivered explicitly on the teaching materials.

In the $9^{\text {th }}$ grade, there were only 2 of $15(13.3 \%)$ educational subjects (social sciences and mathematics for national examination), which did not contain safety education. The $9^{\text {th }}$ grade had 11 subjects as follows: English language, Islamic education, civic education, Indonesian language, mathematics, art, Javanese language, social science, natural science, biology, and physic. They had 124 chapters and 284 themes. These subjects were supported by 15 teaching materials to prepare the student to take on national examination. Among 284 themes in all subjects on the $9^{\text {th }}$ grade, there were $28.13 \%$ themes with safety education and $13 \%$ of them were delivered explicitly on the teaching materials. 
According to the conclusion, we would like to give these following advice: teacher competency in applied science of safety must be enhanced. Therefore, the teacher can improve or develop the theory into the real example of implementation of safety education during the teaching process, especially in the subject that did not contain the safety education, such as social science, mathematics, Javanese language, and Islamic education. Moreover, teachers are expected to deliver the safety education in details to the students in the subjects that related to laboratory activities, thematic subjects, and local content subjects. Also, they are also expected to be able to integrate safety education into extracurricular activities in school.

\section{ACKNOWLEDGMENT}

Implementation of this research was funded by the Competitive Research Grant Scheme by Sport Science Faculty of Universitas Negeri Semarang. In addition, we give our greatest gratitude to the services, opportunities, and trust to Sport Science Faculty, Universitas Negeri Semarang.

\section{REFERENCES}

[1] S. Kuschithawati, et al., "Risk Factors of Injury among Children In Primary School," IEEE Transl. BKM, vol. 23, no. 3, pp. 131, September 2007.

[2] F. E. Hutasoit, "Knowledge of Primary School Children's Learning About Safety Education (Case Study In Private Elementary School Pangudi Luhur Bernadus 02 Semarang)," Gambaran Pengetahuan
Anak Sekolah Dasar Tentang Safety Education (Studi Kasus Di Sekolah Dasar Swasta Pangudi Luhur Bernadus 02 Semarang), 2016, unpublished.

[3] A. E. Olowokerea, F. A. Okanlaw, "Assessment of vulnerability status of public school children and existing school health programmes in Osun State, Nigeria," International Journal of Africa Nursing Sciences 4, pp. 42-50, 2016. Journal homepage: www.elsevier.com/locate/ijans.

[4] E. Widowati, H. Koesyanto, Sugiharto, "Identification of the Safety Application in Teaching Materials of Primary School (Case Study In State Elementary School Petompon 2)," IEEE Transl. unpublished.

[5] Y. Sukarmin, Sumaryanti, "Implementation of Safety Education in Sport Learning," IEEE Transl. Jurnal Kependidikan, vol. 1, no. 1, pp. 24-37, Juni 2017.

[6] A. Sakurai, M. B. F. Bisri, T. Oda, R. S. Oktari, Y. Murayama, "Assessing school disaster preparedness by applying a comprehensive school safety framework, A case of elementary schools in Banda Aceh City," IOP Conference Series: Earth and Environmental Science, 2016.

[7] S. J. Li, C. S. Wu, H. T. Wong, "School Safety And Children Health In A Post-Disaster Community: Implications To Collaborative Care And Service Learning In School Health," Jurnal of Acute Disease, pp. 46-50, 2016.

[8] Yusvita, Fierdania, "Safety Education At School/I SDN 11 Pagi Duri Kepa West Jakarta," IEEE Transl. Jurnal Abdimas, vol. 3, no. 1, pp. 4550, 1 September 2016,

[9] G. Sugiyanto, M. Y. Santi, "Characteristics of Traffic Accidents and Traffic Safety Education Since Early Age: Case Study in Purbalingga District," IEEE Transl. Jurnal Ilmiah Semesta Teknika, vol. 18, no. 1, pp. 65-75, Mei 2015.

[10] N. L. Ali, C. G. Ta, Zakaria, Mokhtar, Halim, "Pembangunan Satu Pendekatan bagi Memperkasakan Sistem Keselamatan Makmal Sains Sekolah di Malayasia (Developing an Approach to Enhance School Laboratory Safety in Malaysia)," Jurnal Pendidikan Malaysia, vol. 39, no. 2, pp. 153-160, 2014. 